Available online on 15.07.2018 at http://jddtonline.info
Journal Of Drug Delivery and Therapeutics
Open Access to Pharmaceutical and Medical Research
$\begin{gathered}\text { C 2011-18, publisher and licensee JDDT, This is an Open Access article which permits unrestricted non- } \\ \text { commercial use, provided the original work is properly cited }\end{gathered}$

Open $\odot$ Access

Research Article

\title{
FORMULATION AND EVALUATION OF TASTE MASKED FAST DISSOLVING TABLET OF PRAZOSIN HYDROCHLORIDE
}

\author{
Aher Smita ${ }^{*}$, Saudagar Ravindranath ${ }^{1}$, Chaudhari Dhanshri ${ }^{2}$ \\ ${ }^{1}$ Department of Pharmaceutical Chemistry, R.G. Sapkal College of Pharmacy, Anjaneri, Nashik, Maharashtra, India- 422 213 \\ ${ }^{2}$ Department of Quality Assurance Techniques, R.G. Sapkal College of Pharmacy, Anjaneri, Nashik, Maharashtra, India- 422 213
}

\section{ABSTRACT}

The objective of this study was to control the elevated blood pressure in the patient with sudden episode of high blood pressure having markedly reduced function ability and restlessness. In such a case rapid onset of action is required. Prazosin Hydrochloride is drug with short biological half life. The purpose of study is to mask the bitter taste of drug and provide rapid onset of action. Inclusion complex of drug and $\beta$-Cyclodextrin can prepare by kneading method to mask the bitter taste of drug. $3^{2}$ full factorial design was implemented, direct compression method were used to prepare tablet. F2 batch among all other batches showed disintegration time $55 \mathrm{sec}$ with $98.56 \%$ drug release within $5 \mathrm{~min}$. thus it can be concluded the fast dissolving tablet can be formulated for antihypertensive drug.

Keyword: Prazosin Hydrochloride, $\beta$-Cyclodextrin, Kneading method, Inclusion Complex, Antihypertensive, Drug Release.

Article Info: Received 11 May, 2018; Review Completed 04 July 2018; Accepted 07 July 2018; Available online 15 July 2018

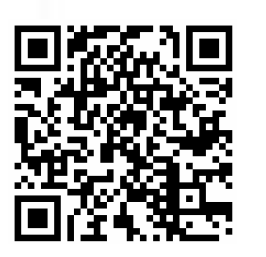

\section{Cite this article as:}

Aher S, Saudagar R, Chaudhari D, Formulation and evaluation of taste masked fast dissolving tablet of prazosin hydrochloride, Journal of Drug Delivery and Therapeutics. 2018; 8(4):263-271 DOI: http://dx.doi.org/10.22270/jddt.v8i4.1785

Aher Smita, Department of Pharmaceutical Chemistry, R.G. Sapkal College of Pharmacy, Anjaneri, Nashik, Maharashtra, India- 422 213

\section{INTRODUCTION}

A wide variety of pharmaceutical research is directed at developing new dosage forms. Most of these efforts have focused on either formulating novel drug delivery systems or increasing the patient compliance. Fast dissolving tablet (FDT) is the most widely preferred commercial products. Drug delivery through oral route is the most preferred and accepted way of application by the patients. ${ }^{1}$ The most popular dosage form being tablets and capsules, one important disadvantage of these dosage forms is the difficulty to swallow. Dysphagia is also associated with a number of medical conditions including stroke, Parkinson's disease, AIDS, head and neck radiation therapy and other neurological disorders including cerebral palsy. Fast dissolving tablet have major advantages that is there is no need of water for administration, rapid onset of action, reduce risk of suffocation, avoid hepatic first pass metabolism. ${ }^{1}$ The one of the most significant issue with FDT is the bitterness of the drug that can be exposed to taste bud as the tablet breaks apart in the oral cavity. Skillful taste masking technique is needed to hide this bitterness like formation of inclusion complex, polymer coating, resin complex. ${ }^{2}$

Prazosin Hydrochloride is a sympatholytic drug used to treat high blood pressure, It is an $\alpha_{1}$-blocker that acts as an inverse agonist at alpha-1 adrenergic receptors. These receptors are found on vascular smooth muscle, it can release catecholamines and hence vasoconstrictor effect can be minimized. The aim of the present study was to develop a fast dissolving tablet of Prazosin Hydrochloride by direct compression and to mask the bitter taste of Prazosin Hydrochloride. Such tablet should dissolve rapidly in the saliva without need of water and release the drug rapidly for immediate therapeutic effect, and be of acceptable taste. ${ }^{3}$ 


\section{MATERIAL AND METHOD}

Prazosin Hydrochloride was purchese from Swapnroop Drugs and Chemicals, Aurangabad. $\beta$-Cyclodextrin was gift sample from Glenmark Pharmceutical, Nashik. All reagents and solvents used in the study were of analytical grade.

Method

\section{Formation of Drug $+\beta-$-Cyclodextrin Inclusion Complex}

Accurately weigh quantity of physical mixture of Prazosin Hydrochloride and $\beta$-Cyclodextrin was triturated in mortar and pestle with small amount of water. The thick slurry was kneaded until mild dryness (40min). The obtain dried mass was then pulverized and sieved through \#44 4

\section{Table 1: Composition of various Inclusion Complexes}

\begin{tabular}{|l|l|l|}
\hline S. N. & Composition (Drug : $\beta$-Cyclodextrin) & Ratio \\
\hline 1 & Prazosin Hydrochloride $+\beta$-yclodextrin & 1.3 \\
\hline 2 & Prazosin Hydrochloride $+\beta$-yclodextrin & 1.5 \\
\hline 3 & Prazosin Hydrochloride $+\beta$-yclodextrin & 1.7 \\
\hline
\end{tabular}

\section{Physical Characterization of Inclusion Complex}

Production Yield: The production yield formulation was calculated using the weight of final product after drying with respect to the initial total weight of the drug and carrier used for the preparation of complex. Percent production yields were calculated as per the formula mentioned below,

$$
\mathrm{Py}=\frac{\mathrm{W} 0}{\mathrm{Wt}} \times 100 \quad \text { Where, }
$$

Py $=$ Production yield,

$\mathrm{W} 0=$ Practical mass (inclusion complex).

$\mathrm{Wt}=$ Theoretical mass (carrier + drug $)$.

\section{Drug content:}

About $5 \mathrm{mg}$ drug equivalent were weighed accurately and transferred to $100 \mathrm{ml}$ volumetric flask. From this stock solution $(100 \mu \mathrm{g} / \mathrm{ml}), 1 \mathrm{ml}$ was withdrawn and further diluted up to $10 \mathrm{ml}$ with Methanol. This solution was used for the assay for drug content by UV spectrophotometer at $246 \mathrm{~nm}$. Concentration of drug in stock solution was calculated by using calibration curve and from which percentage drug content in complex was calculated. ${ }^{5}$

\section{Taste Masking Evaluation method}

\section{Spectrophotometric Method:}

Weigh accurately known amount (10mg) of taste masked formulation and mixed with $10 \mathrm{ml}$ of distilled water in $10 \mathrm{ml}$ syringe. The syringe was revolving end to end five times in 30 seconds. The test medium was filtered through membrane filter. The absorbance was recorded on UV spectrophotometer at $246 \mathrm{~nm}^{.5,6}$

\section{Fourier Transform Infrared Spectroscopy of Prazosin Hydrochloride:}

The infrared spectra of pure Prazosin Hydrochloride were taken on Bruker FTIR spectrometer. Samples were prepared by $\mathrm{KBr}$ disc method ( $2 \mathrm{mg}$ sample in $100 \mathrm{mg}$ $\mathrm{KBr}$ ) and examined in the transmission mode. Each spectrum was measured over a frequency range of 4000$400 \mathrm{~cm}^{-1.7-9}$

\section{Differential Scanning Colorimetry (DSC)}

The DSC measurements were performed on a DSC 60, Shimadzu, Japan differential scanning calorimeter with thermal analyzer. All accurately weighed samples were placed in a sealed aluminium pans, before heating under nitrogen flow $(10 \mathrm{ml} / \mathrm{min})$ at a scanning rate of $10{ }^{\circ} \mathrm{C}$ per min from 25 to $300{ }^{\circ} \mathrm{C}$. An empty aluminium pan was used as reference. ${ }^{10}$

\section{Powder X-Ray Diffraction (P-XRD)}

For the structural, crystal, and physical state characterization of Prazosin Hydrochloride, X-Ray diffraction studies were performed for pure drug, Prazosin Hydrochloride and Inclusion Complex. XRD study was carried out with Bruker AXS D8 Advance with Vertical, Theta/2 geometry using copper target, a voltage of $40 \mathrm{kv}$ and a current of $35 \mathrm{~mA}$. The scanning was done over $2 \theta$ range of $3^{\circ}$ to $135^{\circ}$.

\section{Method of Preparation of Powder Blend}

Inclusion complex of Prazosin Hydrochloride and other inactive ingredients except Sodium starch glycolate and Talc were mixed by using glass mortar and pestle and passed through sieve no. 60. The mixed material blended with Sodium starch glycolate and Talc. The whole mixture was passed through Sieve No. 60 twice. Tablets were prepared using $8 \mathrm{~mm}$ round flat-faced punch of the rotary tablet machine [Rimek, Mini Press-1, Karnavti]. Compression force was constant for all formulations.

\section{$3^{2}$ Full Factorial Design}

Table 2: Formula for Fast Dissolving Tablet of Prazosin Hydrochloride

\begin{tabular}{|l|l|l|l|l|l|l|l|l|l|l|}
\hline S.N. & Ingredient & F1 & F2 & F3 & F4 & F5 & F6 & F7 & F8 & F9 \\
\hline $\mathbf{1}$ & $\begin{array}{l}\text { Drug + } \boldsymbol{\beta} \text {-CD Inclusion Complex } \\
\text { equivalent to 5mg of drug }\end{array}$ & 40 & 40 & 40 & 40 & 40 & 40 & 40 & 40 & 40 \\
\hline $\mathbf{2}$ & Sodium Starch Glycolate & 2 & 5 & 8 & 2 & 5 & 8 & 2 & 5 & 8 \\
\hline $\mathbf{3}$ & D-Mannitol & 20 & 20 & 20 & 40 & 40 & 40 & 60 & 60 & 60 \\
\hline $\mathbf{4}$ & Magnesium Stearate & 3 & 3 & 3 & 3 & 3 & 3 & 3 & 3 & 3 \\
\hline $\mathbf{5}$ & Talc & 2 & 2 & 2 & 2 & 2 & 2 & 2 & 2 & 2 \\
\hline $\mathbf{6}$ & Lactose & q.s & q.s & q.s & q.s & q.s & q.s & q.s & q.s & q.s \\
\hline & Total(mg) & 180 & 180 & 180 & 180 & 180 & 180 & 180 & 180 & 180 \\
\hline
\end{tabular}




\section{Evaluations of powder blend for flow properties: ${ }^{13}$}

\section{Bulk Density:}

An accurately weighed powder blend from each formula was lightly shaken to break any agglomerates formed and it was introduced in to a measuring cylinder. The volume occupied by the powder was measured which gave bulk volume. Bulk density of powder blends was determined using the following formula.

Bulk density $=$ Total weight of powder / Total volume of powder

\section{Tapped density:}

An accurately weighed powder blend from each formula was lightly shaken to break any agglomerates formed and it was introduced into a measuring cylinder. The measuring cylinder was tapped until no further change in volume was noted which gave the tapped volume. The tapped densities (TD) of powder blends were determined using the following formula.

Tapped bulk density $=$ Total weight of powder $/$ Total volume of tapped powder

\section{Angle of repose:}

The frictional forces in a loose powder or granules can be measured by the angle of repose. This is the maximum angle possible between the surface of a pile of powder or granules and the horizontal plane.

$\tan \theta=\mathrm{h} / \mathrm{r} \theta=\tan -1(\mathrm{~h} / \mathrm{r})$

Where, $\theta$ is the angle of repose,

$\mathrm{h}$ is the height, $\mathrm{r}$ is the radius.

\section{Hausner Ratio:}

Hausner's ratio is an indirect index of ease of powder flow.

It is calculated by the following formula Hausner's ratio $=\mathrm{d}$ When $\mathrm{t}$ is the tapped density and $\mathrm{b}$ is bulk density.

\section{Compressibility Index:}

Percent compressibility of powder mix was determined by Carr's compressibility index calculated by following formula.

Carr's Index \%= TBD - LBD x 100 TBD

Where, LBD = Loose Bulk Density

TBD $=$ Tapped Bulk Density

\section{Evaluation of FDT of Prazosin Hydrochloride ${ }^{12,13}$}

\section{Thickness:}

The thickness of tablet is important for uniformity of tablet size. The thickness of the tablets was determined using a Vernier Calliper. Three tablets from each batch were used.

\section{Hardness:}

Hardness indicates the ability of a tablet to withstand mechanical shocks while handling. The hardness of the tablets was determined using Pfizer hardness tester. It is expressed in $\mathrm{kg} / \mathrm{cm}^{2}$.

\section{Drug Content Uniformity Study:}

Twenty tablets were weighed individually and powdered. The powder equivalent to $5 \mathrm{mg}$ of Prazosin Hydrochloride was weighed and dissolved in Phosphate Buffer $\mathrm{pH}$ 6.8. The volume was made to 100 with Phosphate Buffer $\mathrm{pH}$ 6.8. From this stock solution, 10 $\mu \mathrm{g} / \mathrm{ml}$ dilution of the drug was prepared. The drug contents of the resulting solution were calculated from UV absorbance at $246 \mathrm{~nm}$.

\section{Friability:}

Roche friabilator is the equipment which is used for the determination of friability. It is expressed in percentage. Note down the initial weight of the tablets individually (W initial). Tablets are placed in a plastic chamber which revolves at $25 \mathrm{rpm}$ and they are subjected to fall from a height of 6 inches in the friabilator for about 100 revolutions. Then measure the weight of the tablet (W final) and observe any weight difference before tablet and after the friabilator processing.

Limits: loss in weight less than 0.5 to $1 \%$ of the initial weight of the tablet should be considered as acceptable limits.

$\mathrm{F}=\{(\mathrm{W}$ initial $)-(\mathrm{W}$ final $) /(\mathrm{W}$ initial $)\} \times 100$.

\section{Weight Variation:}

Twenty tablets were weighed individually. Average weight tablet was calculated from the total weight of all tablets. The individual weights were compared with the average weight. The percentage difference in the weight variation should be within the acceptable limits $( \pm 7.5 \%)$. The percent deviation was calculated using the following formula.

$$
\% \text { Deviation }=\frac{\text { Individual weight }- \text { Average weight }}{\text { Average weight }} \times 100
$$

\section{Wetting Time:}

The method was applied to measure tablet-wetting time. A piece of tissue paper folded twice was placed in a small petridish (i.d. $=6.5 \mathrm{~cm}$ ) containing $6 \mathrm{ml}$ of water, a tablet was put on the paper, and the time for complete wetting was measured. Three trials for each batch were performed and standard deviation was also determined

\section{Disintegration Time Study:}

The in-vitro disintegration studies were carried out using Tablet Disintegration Test Apparatus. One tablet was placed in each of the six tubes of the basket assembly and disk was added to each tube. This assembly was then suspended in one-liter beaker containing water maintained at $37 \pm 2^{\circ} \mathrm{C}$. The basket was then moved up and down through a distance of 5 to $6 \mathrm{~cm}$ at a frequency of 28 to 32 cycles per minutes. The time required for complete disintegration of the tablet was recorded.

\section{In- vitro Drug Release Study:}

An in-vitro drug release studies of the prepared nine formulations of Fast dissolving tablet were conducted for a period of 5 minutes using an eight station USP type 2 apparatus (paddle type). The agitation speed was 50 rpm. Prazosin Hydrochloride tablet were added to 900 
$\mathrm{ml}$ of phosphate buffer $\mathrm{pH} 6.8$ at $37 \pm 0.5^{\circ} \mathrm{C} .5 \mathrm{ml}$ aliquots were withdrawn at time intervals of $1,2,3,4$ and $5 \mathrm{~min}$ and filtered through Whatmans filter paper No. 41. An equal volume of fresh dissolution medium was replaced to maintain the volume of dissolution medium. The filtered samples were analyzed spectrophotometrically at $246 \mathrm{~nm}$. Cumulative percentage of labelled amount of drug released was calculated.

\section{Dissolution Kinetics:}

Formulation of fast dissolving tablet applied various kinetic release model such as Zero order, First Order, Higuchi and Connor's and Korsemeyer's Peppas. Fast dissolving tablet of Prazosin Hydrochloride follow First order release kinetic, the mechanism of first order kinetic is Non-fickian diffusion.

\section{Stability Studies:}

The optimized formulation was wrapped in aluminum foil and subjected to $40 \pm 2{ }^{\circ} \mathrm{C}$ temperature and $75 \pm 5 \%$ $\mathrm{RH}$ in oven for the period of three months. The formulation was analyzed for organoleptic characteristics, thickness, hardness, drug content, wetting time, disintegration time, weight variation, and dissolution $^{.15}$

\section{RESULT AND DISCUSSION}

\% Drug Content and Production Yield of Inclusion Complex

Table 3: Percent Drug Content and Production Yield of Drug: $\beta$-Cyclodextrin Inclusion Complex

\begin{tabular}{|c|c|c|}
\hline Ratio of Drug: $\beta$-Cyclodextrin & \% Drug Content & Production Yield \\
\hline 1.3 & 97.19 & $84.25 \%$ \\
\hline 1.5 & 96.15 & $71.10 \%$ \\
\hline 1.7 & 98.62 & $90.12 \%$ \\
\hline
\end{tabular}

Table 4: Evaluation of Taste Masking by UV Spectrophotometric method

\begin{tabular}{|c|c|c|}
\hline S. N. & Absorbance of Drug Solution (246nm) & Absorbance of Inclusion Complex (246) \\
\hline 1 & 3.176 & 2.688 \\
\hline 2 & 3.152 & 2.675 \\
\hline 3 & 3.155 & 2.676 \\
\hline
\end{tabular}

Table 5: Result of Phase solubility study of various ratios of Inclusion Complex

\begin{tabular}{|c|c|c|c|c|c|}
\hline S. $\mathbf{N}$. & Drug & Polymer & Ratio & $\begin{array}{c}\text { Solubility } \\
(\mathbf{m g} / \mathbf{m l})\end{array}$ & $\begin{array}{c}\text { Fold increase } \\
\text { in solubility }\end{array}$ \\
\hline 1 & Prazosin Hydrochloride & - & - & 0.00221 & - \\
\hline 2 & Prazosin Hydrochloride & $\beta-$ CD & $1: 3$ & 0.1050 & 4.6 \\
\hline 3 & Prazosin Hydrochloride & $\beta-C D$ & $1: 5$ & 0.0450 & 2.1 \\
\hline 4 & Prazosin Hydrochloride & $\beta-C D$ & $1: 7$ & 0.1632 & 7.9 \\
\hline
\end{tabular}

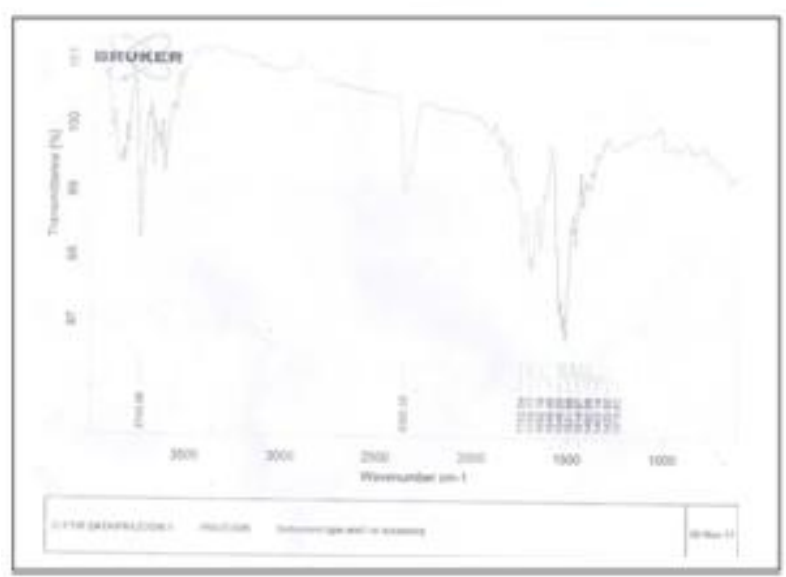

Figure 1: FT-IR Spectrum of Pure Drug

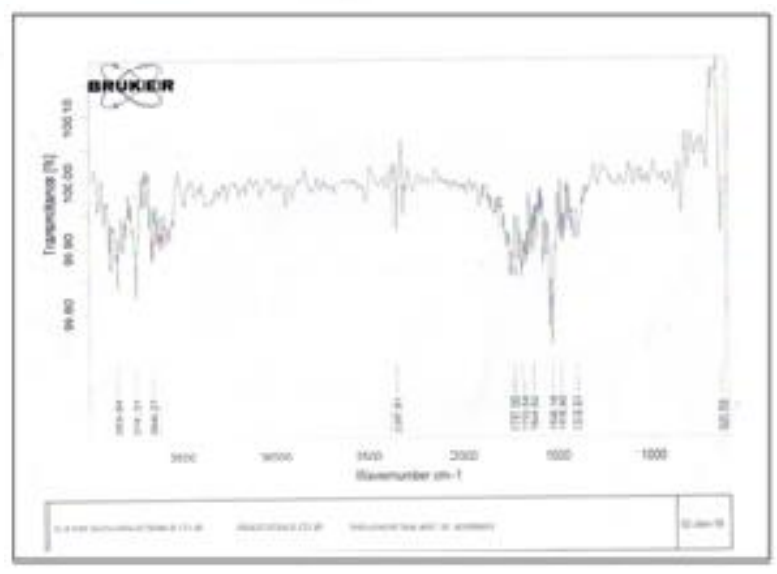

Figure 2: FT-IR Spectrum of Inclusion Complex (1:7) 
Table 6: FTIR Peaks of Prazosin Hydrochloride

\begin{tabular}{|l|l|l|l|l|}
\hline $\begin{array}{l}\text { Observed Values } \\
\text { Peaks }\left(\mathbf{c m}^{-1}\right)\end{array}$ & $\begin{array}{l}\text { Standard Values } \\
\text { Peaks }\left(\mathbf{c m}^{-1}\right)\end{array}$ & $\begin{array}{l}\text { Spectrum of Prazosin } \\
\text { Hydrochloride Assignment }\end{array}$ & Pure Drug & $\begin{array}{l}\text { Inclusion } \\
\text { Complex }\end{array}$ \\
\hline 3743 & $>3000$ & =CH aromatic ring & Yes & Yes \\
\hline 1753.54 & $1750-1680$ & C=O stretching & Yes & Yes \\
\hline 1646 & $1560-1650$ & N-H bending & Yes & Yes \\
\hline 1310 & $1000-1320$ & C-O stretching & Yes & Yes \\
\hline
\end{tabular}

DSC Study of Prazosin Hydrochloride

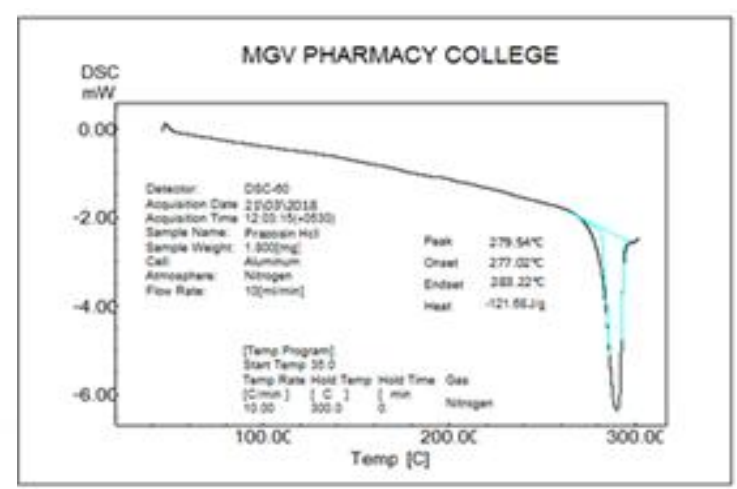

Figure 3: Differential Scanning Calorimetr Thermogram of pure drug Prazosin Hydrochloride

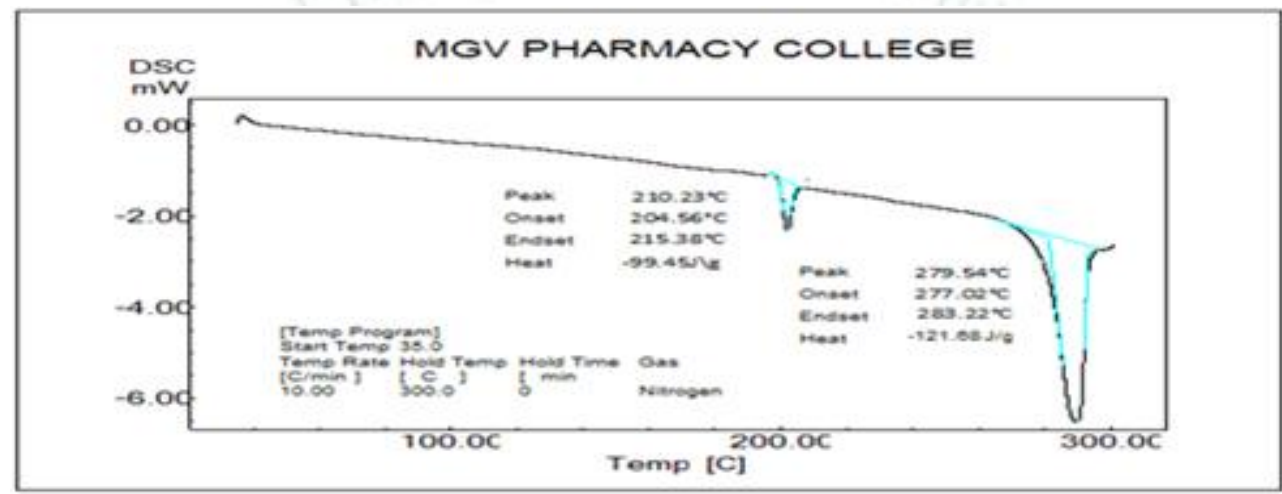

Figure 4: Differential Scanning Calorimetry Thermogram of Inclusion Complex

Table 7: Interpretation of DSC Thermogram of prazosin hydrochloride

\begin{tabular}{|c|c|c|}
\hline Parameter & Drug & Inclusion Complex \\
\hline Peak & 279.54 & 210.23 \\
\hline Onset & 277.02 & 204.56 \\
\hline Endset & 283.22 & 215.38 \\
\hline Heat & $-121.68 \mathrm{~J} / \mathrm{g}$ & $-91.45 \mathrm{~J} / \mathrm{g}$ \\
\hline
\end{tabular}

P-XRD Study of Prazosin Hydrochloride

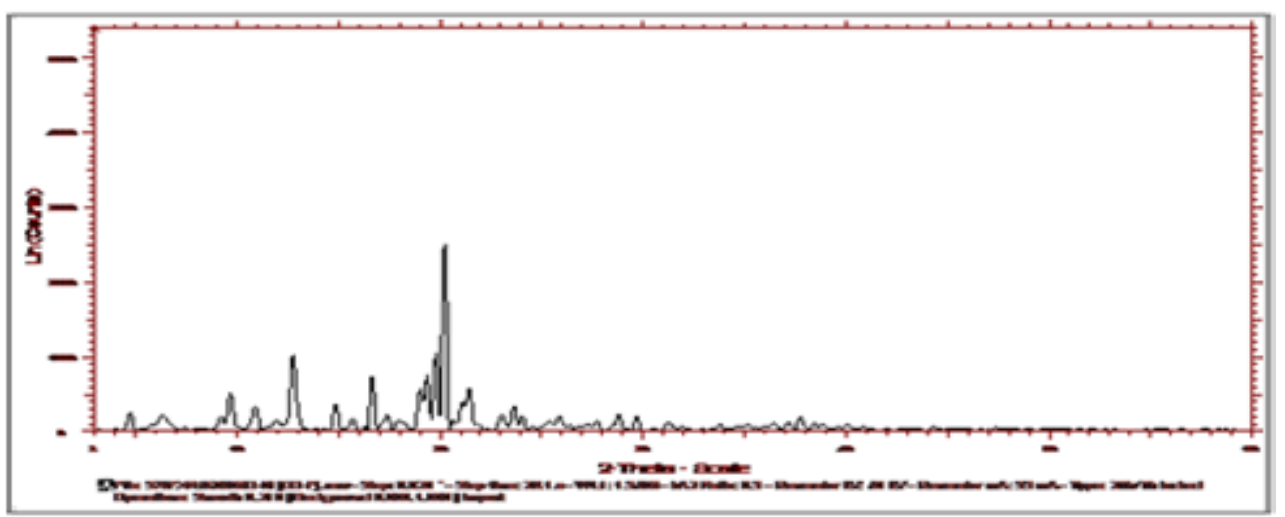

Figure 5: X-Ray Diffraction of Prazosin Hydrochloride 


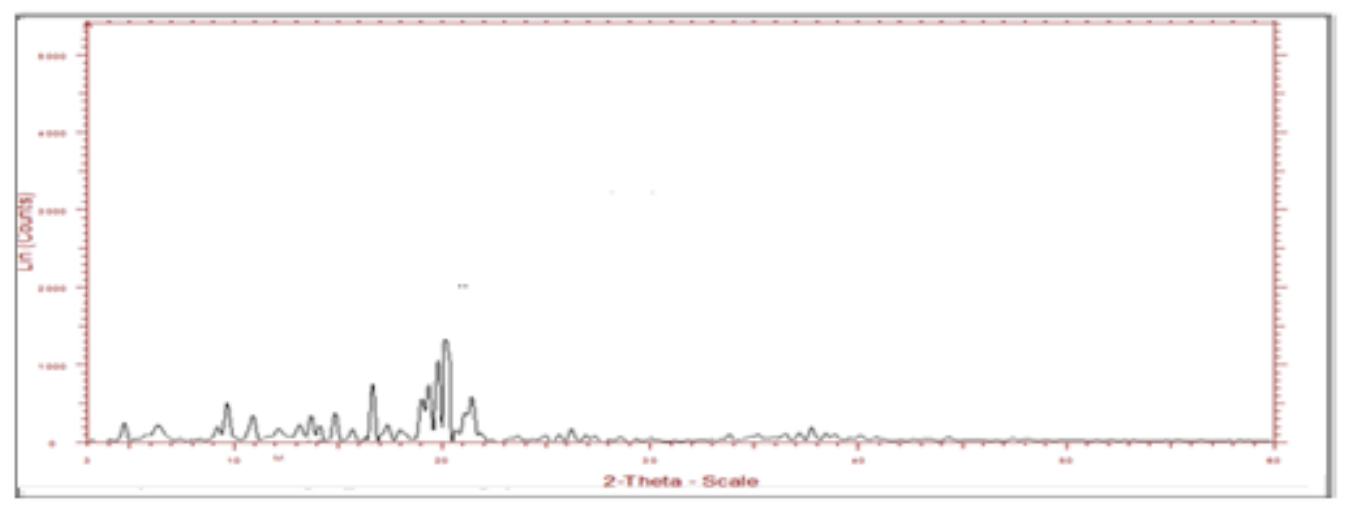

Figure 6: X-Ray Diffraction of $\beta$-Cyclodextrin Inclusion Complex

Table 8: Evaluation of Powder Blend

\begin{tabular}{|c|c|c|c|c|c|}
\hline $\begin{array}{c}\text { Formulation } \\
\text { Batches }\end{array}$ & $\begin{array}{c}\text { Bulk density } \\
(\mathbf{g m} / \mathbf{m l})\end{array}$ & $\begin{array}{c}\text { Tapped density } \\
(\mathbf{g m} / \mathbf{m l})\end{array}$ & $\begin{array}{c}\text { Angle of repose } \\
\mathbf{( \mathbf { C } )}\end{array}$ & $\begin{array}{c}\text { Compressibility Index } \\
(\mathbf{\%})\end{array}$ & $\begin{array}{c}\text { Hausner } \\
\text { Ratio }\end{array}$ \\
\hline F1 & $0.40 \pm 0.090$ & $0.436 \pm 0.021$ & $28.79 \pm 0.60$ & $9.51 \pm 2.79$ & $1.12 \pm 0.053$ \\
\hline F2 & $0.391 \pm 0.017$ & $0.466 \pm 0.015$ & $26.57 \pm 1.37$ & $2.24 \pm 2.13$ & $1.04 \pm 0.021$ \\
\hline F3 & $0.384 \pm 0.022$ & $0.454 \pm 0.040$ & $25.97 \pm 1.97$ & $6.55 \pm 2.03$ & $1.11 \pm 0.11$ \\
\hline F4 & $0.366 \pm 0.025$ & $0.444 \pm 0.025$ & $27.14 \pm 0.61$ & $5.48 \pm 0.18$ & $1.10 \pm 0.041$ \\
\hline F5 & $0.382 \pm 0.015$ & $0.487 \pm 0.035$ & $26.34 \pm 0.66$ & $2.46 \pm 1.26$ & $1.10 \pm 0.094$ \\
\hline F6 & $0.373 \pm 0.027$ & $0.468 \pm 0.021$ & $28.34 \pm 1.14$ & $4.65 \pm 1.16$ & $1.02 \pm 0.081$ \\
\hline F7 & $0.396 \pm 0.017$ & $0.450 \pm 0.014$ & $27.03 \pm 0.99$ & $4.81 \pm 0.19$ & $1.11 \pm 0.069$ \\
\hline F8 & $0.385 \pm 0.017$ & $0.474 \pm 0.018$ & $29.48 \pm 1.19$ & $9.41 \pm 2.51$ & $1.09 \pm 0.025$ \\
\hline F9 & $0.394 \pm 0.015$ & $0.498 \pm 0.017$ & $28.26 \pm 1.05$ & $8.92 \pm 2.36$ & $1.07 \pm 0.061$ \\
\hline
\end{tabular}

Table 9: Evaluation of Prazosin Hydrochloride Fast Dissolving Tablet

\begin{tabular}{|c|c|c|c|c|}
\hline $\begin{array}{c}\text { Formulation } \\
\text { batches }\end{array}$ & $\begin{array}{c}\text { Thickness (mm) } \\
( \pm \mathbf{S D})\end{array}$ & $\begin{array}{c}\text { Hardness }\left(\mathbf{K g} / \mathbf{c m}^{2}\right) \\
( \pm \mathbf{S D})\end{array}$ & $\begin{array}{c}\text { Drug content (\%) } \\
( \pm \mathbf{S D})\end{array}$ & $\begin{array}{c}\text { Friability (\%) } \\
( \pm \text { SD) }\end{array}$ \\
\hline F1 & $3.7 \pm 0.13$ & $3.3 \pm 0.13$ & $97.13 \pm 0.11$ & $0.53 \pm 0.045$ \\
\hline F2 & $3.5 \pm 0.35$ & $3.1 \pm 0.11$ & $98.86 \pm 0.064$ & $0.51 \pm 0.039$ \\
\hline F3 & $3.4 \pm 0.20$ & $3.3 \pm 0.10$ & $96 \pm 0.075$ & $0.42 \pm 0.024$ \\
\hline F4 & $3.5 \pm 0.17$ & $3.4 \pm 0.05$ & $97.11 \pm 0.116$ & $0.42 \pm 0.22$ \\
\hline F5 & $3.2 \pm 0.67$ & $3.2 \pm 0.13$ & $94.78 \pm 0.059$ & $0.44 \pm 0.012$ \\
\hline F6 & $3.4 \pm 0.27$ & $3.3 \pm 0.11$ & $96.42 \pm 0.12$ & $0.51 \pm 0.039$ \\
\hline F7 & $3.3 \pm 0.13$ & $3.2 \pm 0.25$ & $97.47 \pm 0.42$ & $0.55 \pm 0.024$ \\
\hline F8 & $3.4 \pm 0.32$ & $3.4 \pm 0.1$ & $98.02 \pm 0.29$ & $0.44 \pm 0.012$ \\
\hline F9 & $3.4 \pm 0.11$ & $3.2 \pm 0.13$ & $98.56 \pm 0.033$ & $0.55 \pm 0.020$ \\
\hline
\end{tabular}

Table 10: Evaluation of Prazosin Hydrochloride Fast Dissolving Tablet

\begin{tabular}{|c|c|c|c|c|}
\hline $\begin{array}{l}\text { Formulation } \\
\text { batches }\end{array}$ & $\begin{array}{c}\text { Weight variation(mg) } \\
( \pm \mathbf{S D})\end{array}$ & $\begin{array}{c}\text { Wetting time(sec.) } \\
( \pm \mathbf{S D})\end{array}$ & $\begin{array}{c}\text { Water absorption } \\
\text { ratio }(\boldsymbol{\%}) \\
( \pm \text { SD) }\end{array}$ & $\begin{array}{c}\text { Disintegration Time } \\
(\mathbf{s e c}) \\
( \pm \mathbf{S D})\end{array}$ \\
\hline F1 & $179 \pm 0.42$ & $36.00 \pm 1.48$ & $54.8 \pm 0.055$ & $84.45 \pm 0.83$ \\
\hline F2 & $178 \pm 0.55$ & $11.00 \pm 0.83$ & $81.04 \pm 0.045$ & $55.00 \pm 0.81$ \\
\hline F3 & $178 \pm 0.47$ & $21.3 \pm 3.38$ & $66.66 \pm 1.07$ & $71.89 \pm 1.26$ \\
\hline F4 & $178 \pm .041$ & $25.8 \pm 2.77$ & $59 \pm 0.50$ & $75.23 \pm 1.36$ \\
\hline F5 & $178 \pm 0.39$ & $22.00 \pm 2.34$ & $60.16 \pm 0.88$ & $73.00 \pm 1.72$ \\
\hline F6 & $179 \pm .040$ & $15.2 \pm 2.38$ & $76.66 \pm 0.54$ & $66.41 \pm 1.94$ \\
\hline F7 & $179 \pm 0.46$ & $40.00 \pm 2.30$ & $51.16 \pm 0.88$ & $90.00 \pm 2.07$ \\
\hline F9 & $178 \pm 0.39$ & $18.2 \pm 4.76$ & $74.66 \pm 1.08$ & $68.00 \pm 2.44$ \\
\hline
\end{tabular}


Table 11: Dissolution Data of Fast Dissolving Tablets of Prazosin Hydrochloride

\begin{tabular}{|c|c|c|c|c|c|}
\hline $\begin{array}{c}\text { Formulation Batches } \\
\text { \% CDR }\end{array}$ & 1 min & $\mathbf{2 ~}$ min & $\mathbf{3 ~ m i n}$ & $\mathbf{4 ~} \mathbf{~ m i n}$ & $\mathbf{5}$ min \\
\hline F1 & $42 \pm 2.14$ & $53.26 \pm 2.1$ & $70.62 \pm 1.020$ & $79.1 \pm 2.58$ & $85.12 \pm 2.31$ \\
\hline F2 & $52.10 \pm 1.02$ & $64.82 \pm 0.45$ & $77.12 \pm 2.75$ & $86.32 \pm 1.15$ & $98.56 \pm 2.58$ \\
\hline F3 & $46.23 \pm 2.45$ & $57.65 \pm 2.3$ & $73.25 \pm 2.85$ & $82.45 \pm 1.45$ & $91.00 \pm 2.13$ \\
\hline F4 & $43.23 \pm 2.88$ & $55.12 \pm 2.54$ & $72.21 \pm 0.28$ & $80.35 \pm 2.43$ & $86.11 \pm 2.91$ \\
\hline F5 & $48.10 \pm 2.03$ & $54.65 \pm 1.52$ & $73.58 \pm 2.34$ & $81.49 \pm 2.45$ & $90.80 \pm 2.04$ \\
\hline F6 & $50.4 \pm 0.23$ & $61.52 \pm 1.63$ & $75.44 \pm 0.78$ & $84.00 \pm 1.65$ & $95.56 \pm 1.23$ \\
\hline F7 & $41.28 \pm 1.25$ & $52.63 \pm 0.32$ & $68.27 \pm 1.6$ & $76.59 \pm 2.55$ & $82.56 \pm 1.010$ \\
\hline F8 & $49.00 \pm 2.98$ & $60.20 \pm 1.89$ & $75.54 \pm 2.96$ & $83.29 \pm 2.36$ & $94.22 \pm 2.66$ \\
\hline F9 & $47.09 \pm 1.26$ & $59.11 \pm 2.15$ & $74.15 \pm 0.74$ & $81.0 \pm 2.17$ & $92.57 \pm 2.29$ \\
\hline
\end{tabular}

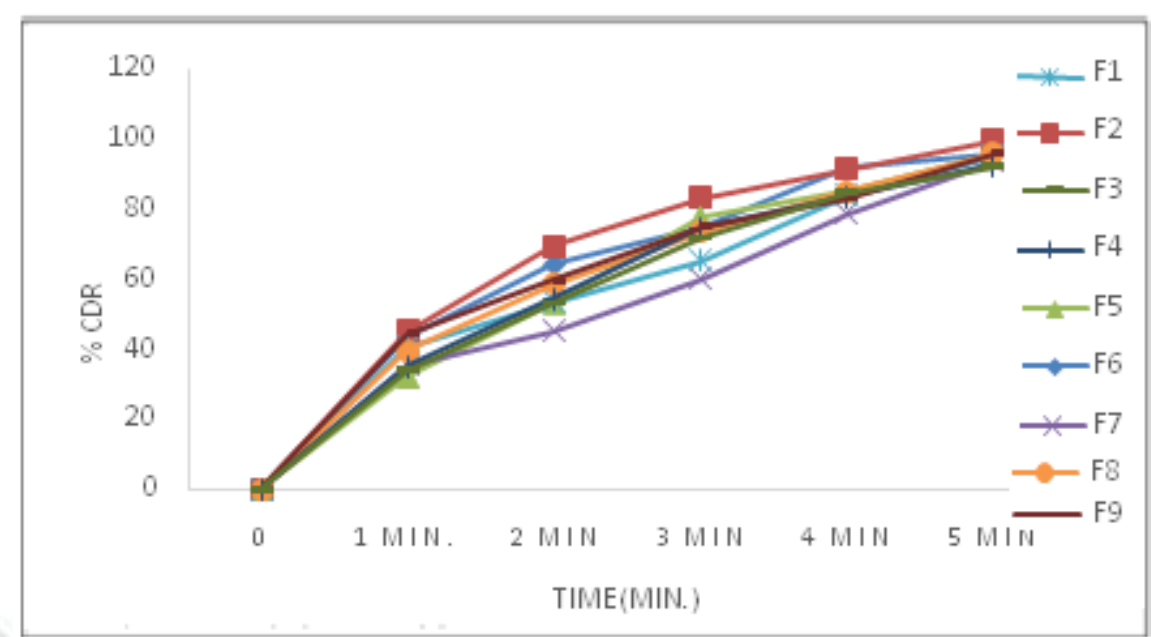

Figure 7: Dissolution profile of fast dissolving tablets of Prazosin Hydrochloride

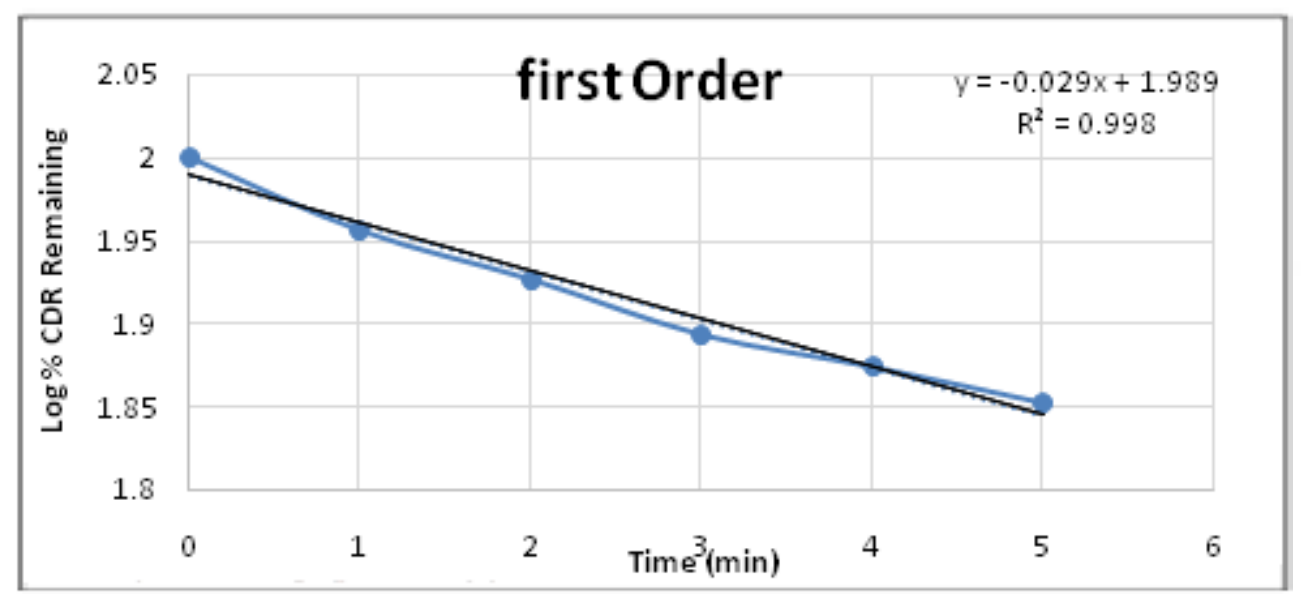

Figure 8: Model graph for comparative evaluation of first order release kinetics.

Table 12: $\mathbf{R}^{2}$ value for various kinetic model

\begin{tabular}{|l|l|}
\hline Kinetic Models & $\mathbf{R}^{\mathbf{2}}$ Value \\
\hline First order release kinetics & 0.998 \\
\hline Zero order release kinetics & 0.905 \\
\hline Higuchi and connor's & 0.990 \\
\hline Korsemeyer's Peppas & 0.895 \\
\hline
\end{tabular}




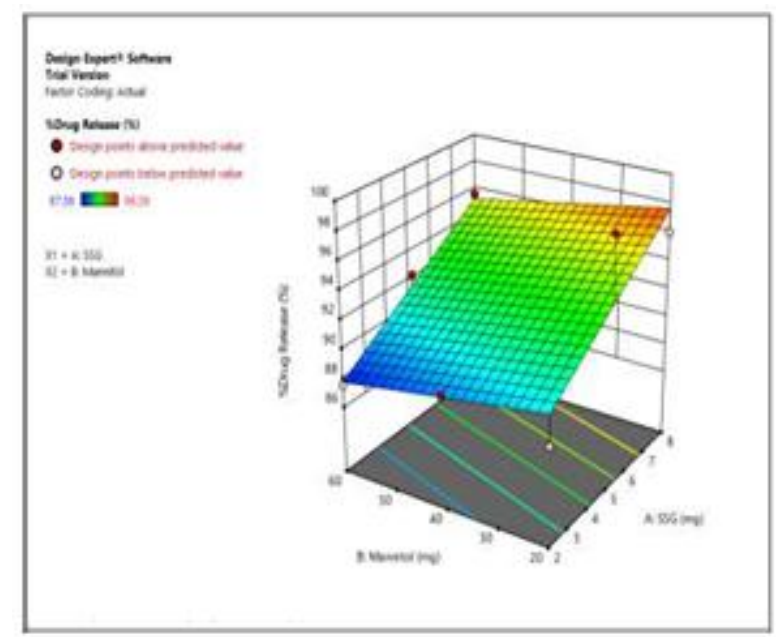

Figure: 9 Surface response plot showing the effect of SSG and Mannitol on \% Drug release of Fast Dissolving Tablet

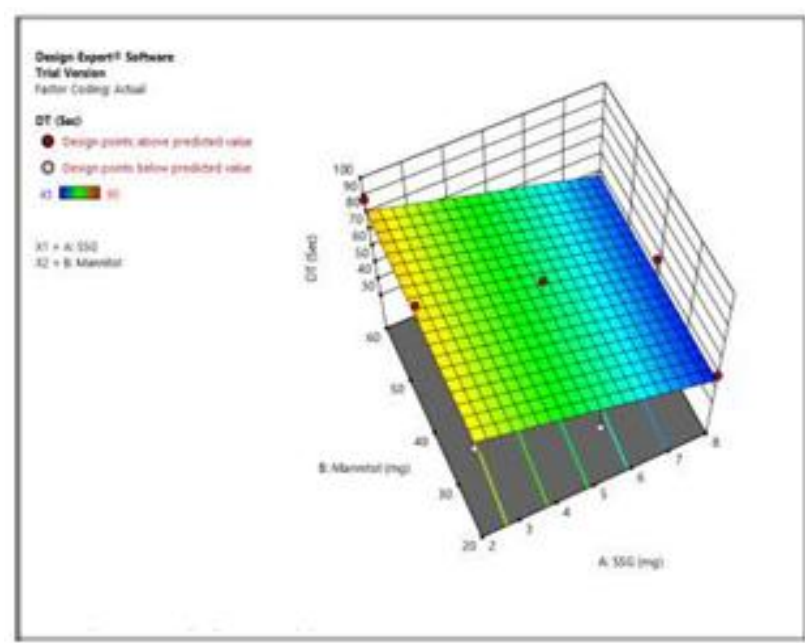

Figure 10: The Surface response plot showing effect of Sodium starch glycolate and Mannitol on Disintegration Time of Fast Dissolving Tablet

Table 13: Result of Stability Study

\begin{tabular}{|l|c|c|c|c|}
\hline \multirow{2}{*}{ Parameters } & \multicolumn{4}{|c|}{ Months } \\
\cline { 2 - 5 } & $\mathbf{0}$ & $\mathbf{1}$ & $\mathbf{2}$ & $\mathbf{3}$ \\
\hline Hardness $\left(\mathrm{kg} / \mathrm{cm}^{2}\right)$ & 3.5 & 3.4 & 3.5 & 3.5 \\
\hline Friability (\%) & 0.51 & 0.53 & 0.54 & 0.53 \\
\hline Disintegration Time(sec) & 55 & 57 & 57 & 56 \\
\hline Drug Content (\%) & 98.71 & 98.58 & 98.21 & 97.52 \\
\hline \% Drug release & 98.56 & 98.59 & 97.87 & 98.12 \\
\hline
\end{tabular}

\section{DISCUSSION}

The model drug selected (Prazosin Hydrochloride) was characterized and analyzed for its physical appearance and solubility, which complies with the monograph as specified in Indian pharmacopoeia and United State pharmacopoeia. UV and IR spectral analysis was done and the drug shows similar data as mentioned in different official publications. By FTIR analysis of pure Prazosin Hydrochloride showed characteristic peaks at $3743 \mathrm{~cm}-1,1753.54 \mathrm{~cm}-1,1646 \mathrm{~cm}-1,1310 \mathrm{~cm}-1$ these are almost same as reported in the monograph for Prazosin Hydrochloride (table 3) Drug-polymer interaction study by FTIR for pure drug, $\beta$-Cyclodextrin and sodium starch glycolate showed that there were no significant changes in the position of the characteristic peaks of drug when mixed with superdisintegrants which indicated compatibility of polymers with the drug.(Figure:1 and2). DSC thermogram of untreated drug shows an endothermic peak at $279.54^{\circ} \mathrm{C}$, which is related to its melting point (Figure 3). The physical mixture of drug and B-Cyclodextrin (Inclusion Complex) has endothermic peak at $268.52^{\circ} \mathrm{C}$ (Figure 4). It was found that there are no new peaks appeared in the thermogram of the drug and excipients. Thus, there is no interaction between the drug and the tablet excipients, was observed. The XRD diffraction pattern of Prazosin Hydrochloride shows sharp peak indicating that the drug is of crystalline nature, while that of Inclusion Complex shows blunt peaks indicating its amorphous nature(Figure 5 and 6).
The \% drug content of various ratio of inclusion complex was found to be $96.15 \%$ - $98.62 \%$ ( table: 3) 1:7 ratio show highest drug content (98.62\%). Production yield of inclusion complex is ranging between $71.10 \%$ - $90.12 \%$ ( table 3) Taste masking evaluation can be done by spectrophotometric method. The conc. of inclusion complex is below the threshold conc. of drug therefore it can be concluded that the bitter taste of drug could be masked. (Table 4). Phase solubility study can be perform with various ratio of drug and B-Cyclodextrin (Inclusion Complex) 1:7 ratio show highest old solubility 7.9 fold, (table 5).

The powder blends is subjected to precompressional evaluation to determine flow property have the bulk density of all formulation are ranged between 0.36$0.40 \mathrm{mg} / \mathrm{ml}$ (table 8 ) Tapped bulk density is ranged between $0.43-0.49 \mathrm{gm} / \mathrm{ml}$. (table 8 ) angle of repose of formulation was found to be between 25-30 indicating excellent flow property. (Table 8) The Hausner's ratio for the formulations was found to be <1.00-1.11, indicating excellent flow properties and indicating good flow property (table 8) The carr's index for the formulations was found to be below $<10 \%$ indicating that the powders have a excellent compressibility(table 8 )

Thickness of Tablet formulations was found to be ranging from $3.2 \mathrm{~mm}$ to $3.7 \mathrm{~mm}$. Variation of thickness in Tablet formulations (F1 to F9) was found within the acceptable limits. (Table 9) Hardness of Tablet formulations was found to be ranging from $3.1 \mathrm{Kg} / \mathrm{cm}^{2}$ 
to $3.4 \mathrm{Kg} / \mathrm{cm}^{2}$. (Table 9) Percent drug content of Prazosin Hydrochloride for all formulation was found in between $98.86 \%$. to $96.00 \%$.(table:9)the friability value ranging from $0.42 \%$ to $0.55 \%$ (table:9) Weight variation for all formulation was found to be in $178 \mathrm{mg}$ to $179.12 \mathrm{mg}$. (Table 10). Sodium starch glycolate was the best superdisintegrant showing the shortest disintegration time. Sodium starch glycolate has powerful swelling capacity thus increase water absorption ratio and result in rapid disintegration. The disintegration time for formulation $\mathrm{F} 1-\mathrm{F} 9$ was found to be in the range of 55 to $90 \mathrm{sec}$. (Table 10) All formulation show quick wetting ranging from 11 to 40sec. (table:10). This may be due to ability of swelling and also capacity of absorption of water. All superdisintegrants have high water absorption capacity water absorption ratio for all formulation was found to be $51.16 \%$ to $81.04 \%$ (table 10 ). \% Drug releases of all formulation are ranging between $82.56 \%$ - 98.56\% (table 11). F2 batch shows highest drug release. Formulation of fast dissolving tablet follow first order release kinetics that is drug released from the system was by Non-fickian diffusion(figure 8 ), $\mathrm{R}^{2}$ value for various kinetic model was showed in (table:12). (table:13) showed that there was no considerable change in Hardness, percent friability, content uniformity, disintegration time, content uniformity and in-vitro drug release of formulation F2 before and after accelerated stability study. Also formulation F2 showed white color after stability studies Hence FDT prepared was found to be stable.

\section{CONCLUSION}

In the present research a successful attempt was made to formulate fast dissolving tablets of Prazosin

\section{REFERENCES}

1. Sharma D, Chopra R, Bedi N, "Development and Evaluation of Paracetamol Taste Masked Orally Disintegrating Tablets Using Polymer Coating Technique" IJPPS; 4(3):129-134.

2. Ratnaparkhi M, "Formulation and Development of Taste Masked Orally Disintegrating Tablets of Perindopril Erbumine by Direct Compression Method" PAA; 3(5):1-10.

3. Rang HP, Dale MM, Ritter JM, Flower RJ, Henderson G. Rang and Dale's Pharmacology. $7^{\text {th }}$ ed. Published by Elsevier Churchill Livingstone; 2012.P. 199-202, 350.

4. Mulay M, Bankar V, "Preparation and Evaluation of Taste Masking Complex of Ciprofloxacin Hydrochloride by Using Inclusion Complexation Approach" WJPR, 2014; 3(5):10351045.

5. Ankita S, "Recent Technologies for The Taste Masking of Bitter Drugs" IJPPR.2012; 3(3):578-585.

6. Sharma D, Kumar D, Singh M, Sing G, Rathore M, "Taste Masking Technologies : A Novel Approach for the Improvement of Organoleptic Property of Pharmaceutical Active Substance" IRJP, 2012; 3(4):108-116.

7. Sharma YR. Elementary Organic Spectroscopy Principle and Chemical Application. $4^{\text {th }}$ ed. New Delhi: S. Chand and Company Ltd Multicolor Edition; P.69-148.
Hydrochloride by direct compression method to improve bitter taste of drug, bioavailability and patient compliance especially for the pediatric and geriatric patients. Prazosin Hydrochloride has poor solubility in water. It is a BCS Class II drug. The present study has shown that it is possible to increase the dissolution rate of poorly soluble drug Prazosin Hydrochloride by preparing it as Inclusion Complex with carriers like $\beta$ Cyclodextrin. Inclusion Complex prepared by kneading method in the ratio of 1:7 for drug where carrier exhibit rapid dissolution rate when compared with pure drug. Fast dissolving tablets of Prazosin Hydrochloride prepared by using various superdisintegrants showed rapid dissolution when compared with the marketed tablets. Based on the study, it may be concluded that Prazosin Hydrochloride tablets prepared by using Inclusion Complex with Sodium Starch Glycolate superdisintegrant was found to be ideal for rapid disintegration and for improving dissolution rate, which in turn increased the bioavailability. Sodium Starch Glycolate was the best superdisintegrant showing the shortest disintegration time. Sodium Starch Glycolate have high water absorption capacity this is necessary to provide the rapid disintegration in the mouth. This study indicates the possibility of utilizing the selected best formulation $\mathrm{F} 2$ in the preparation of Prazosin Hydrochloride fast dissolving tablet as a new dosage form for oral administration having increased solubility, improve bitter taste of drug, improved bioavailability, rapid dissolution and more patient compliance.

Acknowledgement: The authors are greatly acknowledging Glenmark Pharmaceutical, Nashik for supply of $\beta$-Cyclodextrin as a gift sample.

\section{Conflicts of Interest: None}

8. Pavia DL, Lampman GM, Kriz GS. Introduction to Spectroscopy A Guide for Student of Organic Chemistry. $4^{\text {th }}$ ed. Cennage Learning Pvt Ltd; 2007.P. 26-90.

9. Sudhir S, Tiwari A,'Floating Microsphere of Prazosin Hydrochloride: Formulation, Characterization and in-vitro Evaluation" DPL, 2012; 4(4):1327-1338.

10. Kondi V, Allure R, "Optimization And Evaluation of Prazosin Hydrochloride Floating Microspheres Using Response Surface Methodology" JPBS, 2015; 10(3):58-68.

11. Bhise SB, Dias RJ, Dhawale SC, Mali KK. Laboratory Manual of Biopharmaceutics and Pharmacokinetics. Trinity Publishing House; 2010.P. 64-65.

12. The Indian Pharmacopoeia 2014. Government of India, Ministry of Health \& Family Welfare, $7^{\text {th }}$ ed. Vol-II. The Controller of Publication, New Delhi: P. 959-961.

13. Haritha B, "A Review on Evaluation of Tablets" JFSB, 2017; 1(1):1-5

14. Reddy P, Venkateswarlu P, "Design and Characterization of Fast Melt Tablet of Telmisartan” IJIPR, 2014; 5(1):357-363.

15. ICH Harmonised Tripartite Guidelines, International Conference on Harmonisation, Stability Testing of new drug substances and products Q1A(R2) and evaluation for stability data Q1E, Current step version. 6th February 2003. 